\title{
PENINGKATAN PENGETAHUAN LANSIA DALAM UPAYA PENCEGAHAN COVID 19 DI GONDOSULI TAWANGMANGU KARANGANYAR
}

\author{
Tatik Trisnowati \\ Politeknik Insan Husada Surakarta \\ Email Korespondensi: tatiktris@akperinsada.ac.id \\ Disubmit: 18 Juni 2021 Diterima: 05 Juli 2021 Diterbitkan: 01 Februari 2022 \\ DOI: https://doi.org/10.33024/jkpm.v5i2.4552
}

\begin{abstract}
ABSTRAK
COVID-19 disebabkan oleh Coronavirus merupakan kumpulan virus yang bisa menginfeksi sistem pernapasan. Pada banyak kasus, virus ini hanya menyebabkan infeksi pernapasan ringan, seperti flu. Namun, virus ini juga bisa menyebabkan infeksi pernapasan berat, seperti infeksi paru-paru (pneumonia). Virus ini menular melalui percikan dahak (droplet) dari saluran pernapasan, misalnya ketika berada di ruang tertutup yang ramai dengan sirkulasi udara yang kurang baik atau kontak langsung dengan droplet. Pada lansia seiring dengan pertambahan usia, tubuh akan mengalami berbagai penurunan akibat proses penuaan. Sistem imun sebagai pelindung tubuh pun tidak bekerja sekuat ketika masih muda. Sehingga orang lanjut usia (lansia) rentan terserang berbagai penyakit, termasuk COVID-19 yang disebabkan oleh virus Corona. Tujuan dari kegiatan ini adalah meningkatkan pengentahuan lansia dalam upaya pencegahan COVID-19 di Gondosuli, Tawangmangu, Karanganyar. Metode pelaksanaan yang digunakan berupa ceramah dan demonstrasi. Kegiatan di Gondosuli Tawangmangu Karanganyar sangat bermanfaat bagi lansia dan keluarganya. Terdapat adanya peningkatan pengetahuan dan pemahaman lansia dalam upaya pencegahan COVID-19 dimana sebesar $80 \%$ lansia mempunyai pengetahuan dan pemahaman baik.
\end{abstract}

Kata Kunci: Lansia, Pencegahan, COVID-19,

\begin{abstract}
COVID-19 caused by Coronavirus is a collection of viruses that can infect the respiratory system. In many cases, this virus causes only minor respiratory infections, such as flu. However, this virus can also cause severe respiratory infections, such as lung infections (pneumonia). This virus is transmitted through sputum droplets from the respiratory tract, for example when in a closed room with poor air circulation or direct contact with droplets. In the elderly as they age, the body will experience various decreases due to the aging process. The immune system as a body protector doesn't work as well as when you were young. So that the elderly (elderly) are susceptible to various diseases, including COVID-19 which is caused by the Corona virus. The purpose of this activity is to increase the knowledge of the elderly in efforts to prevent COVID19 at Gondosuli Tawangmangu Karanganyar. Method of implementation is lecture and demonstration. Conclusion of health education at Gondosuli Tawangmangu Karanganyar there compliance with the implementation of health
\end{abstract}


protocols and increasing endurance are efforts to prevent COVID-19 where $80 \%$ of the elderly have good knowledge and understanding.

Keywords: Eldery, Prevent, COVID-19.

\section{PENDAHULUAN}

Covid-19 adalah penyakit menular yang disebabkan oleh jenis corona virus yang baru ditemukan. Ini merupakan virus baru dan penyakit yang sebelumnya tidak dikenal sebelum terjadi wabah di Wuhan, Tiongkok, bulan Desember 2019. Corona virus adalah suatu kelompok virus yang dapat menyebabkan penyakit pada hewan atau manusia. Beberapa jenis corona virus diketahui menyebabkan infeksi saluran nafas pada manusia mulai dari batuk pilek hingga yang lebih serius seperti Middle East Respiratory Syndrome (MERS) dan Severe Acute Respiratory Syndrome (SARS) (WHO, 2020).

Menurut Satgas Penanganan covid di Jawa tengah pada tanggal 18 Desember 2020 terdapat jumlah pasien positif terkonfirmasi 69.301 jiwa pasien sembuh 47.196 jiwa dan pasien meningal 2.728 jiwa. Menurut Dinkes Kabupaten Karanganyar pada tanggal 18 Desember 2020 terdapat jumlah pasien covid terkonfirmasi 396 jiwa pasien sembuh 1.831 jiwa pasien meninggal 104 jiwa dan di wilayah Tawangmangu pasien positif covid terdapat 19 jiwa sembuh 72 jiwa dan desa Gondosuli terdapat 1 pasien covid 19. Infeksi virus Corona disebut COVID-19 (Corona Virus Disease 2019) dan pertama kali ditemukan di kota Wuhan, China pada akhir Desember 2019. Virus ini menulardengan sangat cepat dan telah menyebar ke hampir semua negara, termasuk Indonesia, hanya dalam waktu beberapa bulan. Hal tersebut membuat beberapa negara menerapkan kebijakan untuk memberlakukan lockdown dalam rangka mencegah penyebaran virus Corona. Di Indonesia sendiri, diberlakukan kebijakan Pembatasan Sosial Berskala Besar (PSBB) untuk menekan penyebaran virus ini. (Kementerian Kesehatan RI, 2020)

Coronavirus adalah kumpulan virus yang bisa menginfeksi sistem pernapasan. Pada banyak kasus, virus ini hanya menyebabkan infeksi pernapasan ringan, seperti flu. Namun, virus ini juga bisa menyebabkan infeksi pernapasan berat, seperti infeksi paru-paru (pneumonia). Virus ini menular melalui percikan dahak (droplet) dari saluran pernapasan, misalnya ketika berada di ruang tertutup yang ramai dengan sirkulasi udara yang kurang baik atau kontak langsung dengan droplet. Selain virus SARS-CoV-2 atau virus Corona, virus yang juga termasuk dalam kelompok ini adalah virus penyebab Severe Acute Respiratory Syndrome (SARS) dan virus penyebab Middle-East Respiratory Syndrome (MERS). Meski disebabkan oleh virus dari kelompok yang sama, yaitu coronavirus, COVID-19 memiliki beberapa perbedaan dengan SARS dan MERS, antara lain dalam hal kecepatan penyebaran dan keparahan gejala. Pemerintah Indonesia mengeluarkan kebijakan social distancing atau physical distancing (menjaga jarak) sehingga muaranya pada himbauan untuk dirumah saja dan lebih khusus di wilayah yang sudah terdapat pasien Covid- 19. Hal tersebut sejalan dengan hasil penelitian bahwa untuk mengurangi atau memutus mata rantai penularan atau penyebaran infeksi covid-19, dalam upaya ini seseorang harus menjaga jarak dengan orang lain minimal 1-2 meter, dan tidak melakukan kontak langsung dengan orang lain, menghindari kerumunan dan pertemuan masal (Ausrianti, dkk, 2020).

Untuk meningkatkan kesadaran masyarakat dalam pencegahan penularan virus Corona dalam keluarga dan masyarakat perlu dilakukan peningkatan 
pengetahuan melalui pendidikan kesehatan. Peningkatan pengetahuan masyarakat yang dimulai dari keluarga tentang mencegah penularan virus Corona penyebab Covid-19 sangat dibutuhkan untuk meningkatkan implementasi tindakan pencegahan penularan ini sehingga dapat menurunkan angka kejadian penyakit Covid-19. Berdasarkan uraian diatas mengenai Upaya Pencegahan Covid 19, di Desa Gondosuli Tawangmangu terdapat kasus Corona maka penulis ingin memberikan pengetahuan tentang gejala, pola hidup sehat pada saat pandemi dan upaya pencegahanya untuk lansia. Penulis tertarik untuk melakukan kegiatan penyuluhan kesehatan di desa Gondosuli Tawangmangu dan harapannya setelah dilakukan penyuluhan kesehatan mengenai covid 19 lansia bisa menerapkan pola hidup yang tepat pada keseharian.

\section{MASALAH}

Berdasarkan hasil pengkajian yang telah kami lakukan Di desa Gondosuli Tawangmangu ditemukan permasalahan yaitu kurangnya pengetahuan mengenai Covid 19 dan cara mencegahnya, solusi yang kami lakukan dengan memberikan pengetahuan mengenai Covid 19 dari penyebab, gejala dan cara pencegahannya. Kurangnya pengetahuan tentang pola hidup sehat pada masa pandemi covid 19, solusinya kami akan memberikan senam untuk meningkatkan imun dan pemberian minuman herbal untuk meningkatkan imun pada lansia.

Target luaran yang dituju pada kegiatan pengabdian masyarakat adalah lansia di desa Gondosuli Tawangmangu. Peningkatan kesadaran, pengetahuan, maupun perilaku lansia dalam hidup sehat mengenai penyakit Covid 19 sehingga lansia menyadari pentingnya menjaga kesehatan yang baik, saat ini Lansia akan diberi pendidikan kesehatan terkait penyakit covid 19 dan pencegahanya.

Kebutuhan masyarakat/mitra adalah informasi yang tepat tentang COVID-19 secara umum dan cara pencegahannya secara khusus. Sehingga setelah kegiatan iniberlangsung lansia sebagai kelompok rentan mengalami peningkatan pengetahuan dalam upaya pencegahan Covid-19, sehingga mengurangi kecemasan lansia selama pandemi COVID-19 dan lansia tetap sehat dan tidak terinfeski COVID-19. Luaran yang dihasilkan berupa leaflet yang akan dibagikan kepada masyarakat setempat yang berisi tentang covid 19 dan penegahannya.

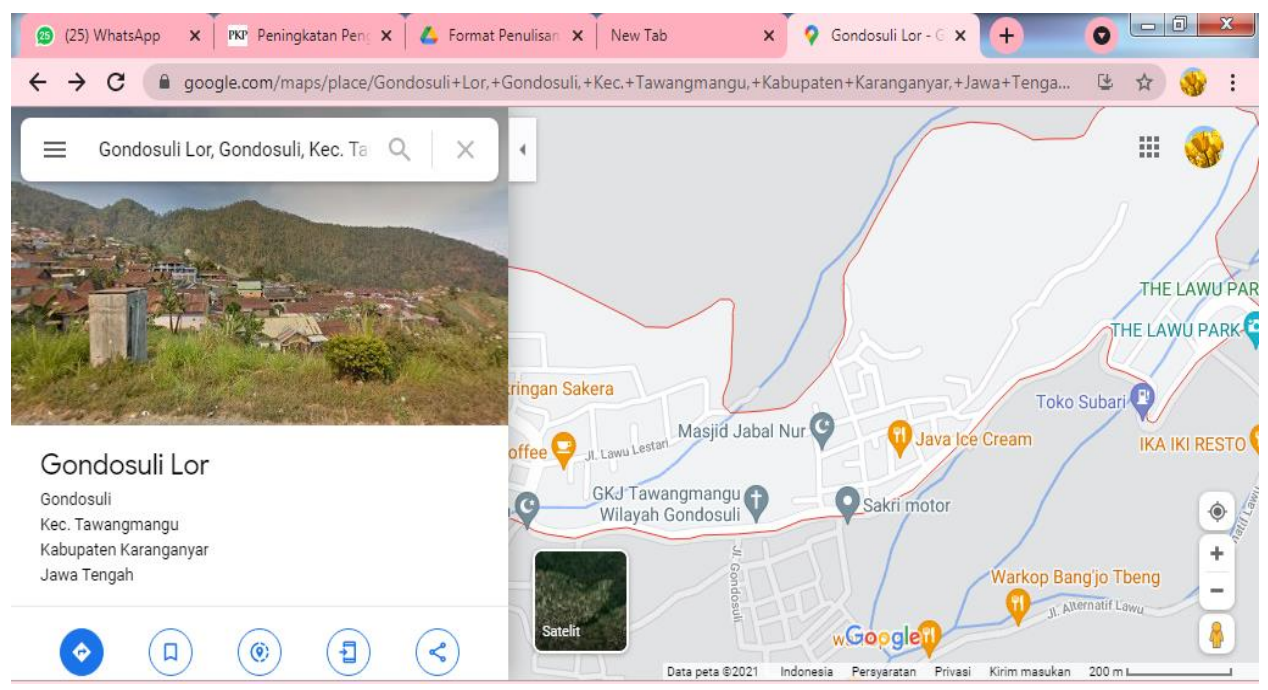

Gambar 1 . Wilayah Gondosuli 


\section{METODE}

a. Tahap persiapan dari kegiatan adalah pembuatan pre-planning, mengajuakan izin dan persiapan tempat dan alat-alat lainnya disiapkan. Pembuatan brousur dimulai 3 hari sebelum kegiatan penyuluhan dimulai. Sesuai dengan tujuan kegiatan ini dilaksanakan untuk meningkatkan pemahaman serta kesadaran peserta (lansia) sebagai upaya pencegahan COVID-19 maka dilakukan dengan teknik penyuluhan dengan metode ceramah, ceramah sebagai metode komunikasi searah secara daring dan diskusi atau tanya jawab sebagai metode komunikasi dua arah dan demontrasi, demonstrasi senam lansia dilakukan secara luring oleh mahasiswa Akademi Keperawatan Insan Husada Surakarta. Hal ini dilakukan karena masih dalam masa pandemi Covid 19 sehingga pemberian materi sebagian dilakukan secara daring, untuk wilayah yang dipilih merupakan wilayah disekitar mahasiswa tinggal.

b. Penyuluhan ini dilakukan pada tanggal 28 Januari 2021 dengan mematuhi protokol kesehatan yang ketat. Untuk mencegah terjadinya kerumunan pada saat kegiatan peserta dibatasi hanya 10 peserta. Selain membatasi jumlah peserta, kegiatan ini juga menjaga jarak antar peserta (1-1,5 m). Peserta wajib menggunakan masker dan tidak dianjurkan membawa anak- anak < usia 10 tahun pada saat kegiatan berlangsung.

c. Evaluasi

1) Pengamatan yang dilakukan jika dijumpai Lansia yang tidak menggunakan masker maka akan di beri edukasi dan pemberian masker gratis

2) Proses pelaksanaan kegiatan dimulai pada pukul 13:00 s/d selesai WIB.

3) Hasil

a) Lansia dapat memahami dan mengerti tentang pengertian covid

b) Lansia dapat memahami dan mengerti tentang cara penularan covid

c) Lansia dapat memahami dan mengerti tentang gejala covid

d) Lansia dapat memahami dan mengerti tentang cara pencegahan covid

e) Lansia mengikuti Senam lansia

\section{HASIL DAN PEMBAHASAN}

Penyuluhan dilakukan semenarik mungkin dengan bahasa yang sederhana yang dapat dimengerti para peserta.

Tabel 1. Distribusi frekuensi Data

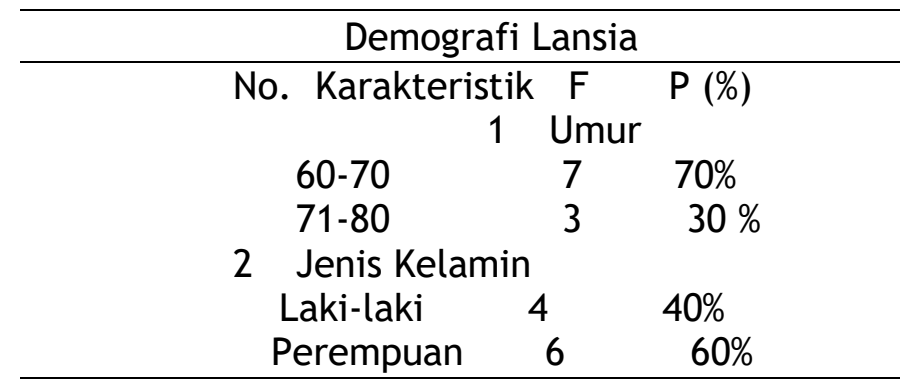

Berdasarkan karakteristik tabel 1 diperoleh gambaran mayoritas responden berusia 60-70 tahun sebanyak 7 responden (70\%) dan sebagian besar berjenis kelamin perempuan sebanyak 6 responden $(60 \%)$. 
Tabel 2. Tingkat Pengetahuan tentang COVID-19

\begin{tabular}{lcccc}
\hline Pengetahuan & Sebelum & \multicolumn{3}{c}{ Sesudah $\%$} \\
\hline Baik & 3 & 30 & 8 & 80 \\
Kurang & 7 & 70 & 2 & 20 \\
\hline $\mathrm{N}$ & 10 & 100 & 10 & 100 \\
\hline
\end{tabular}

Berdasarkan kategori pengetahuan pada tabel 2. Diperoleh gambaran bahwa sebelum diberikan pendidikan kesehatan mayoritas responden pengetahuan tentang penyakit Covid 19 masih kurang yaitu sebesar $70 \%$ dan setelah diberikan pendidikan kesehatan mayoritas responden pengetahuannya meningkat menjadi baik sebesar $80 \%$.

a. Penyuluhan Kesehatan

Penyuluhan dilaksanakan dengan cara ceramah dan tanya jawab dapat berjalan dengan baik dan lancar. Ceramah sebagai metode komunikasi searah secara daring dan diskusi atau tanya jawab sebagai metode komunikasi dua arah.

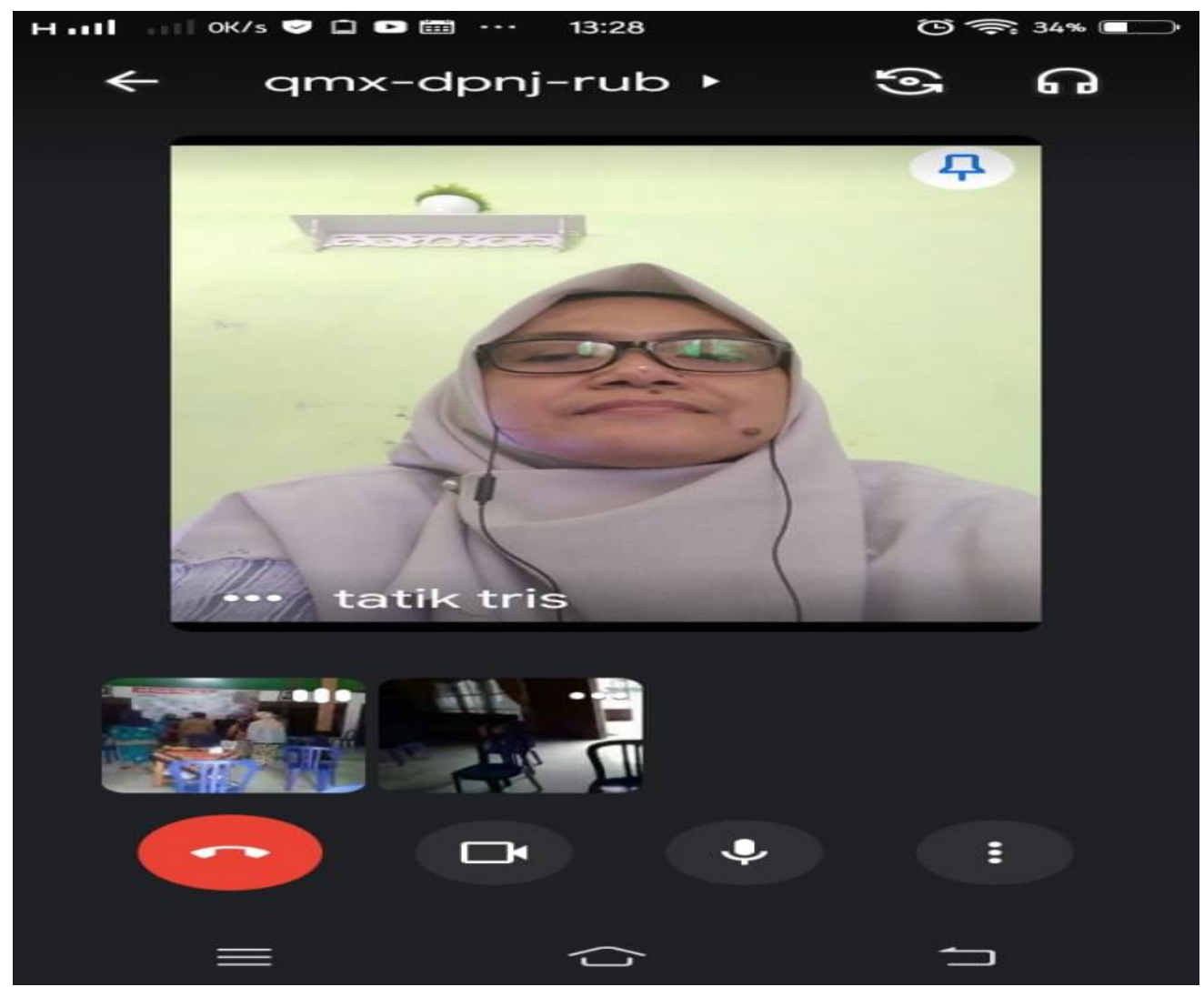

Gambar 2. Penyuluhan kesehatan dan tanya jawab 


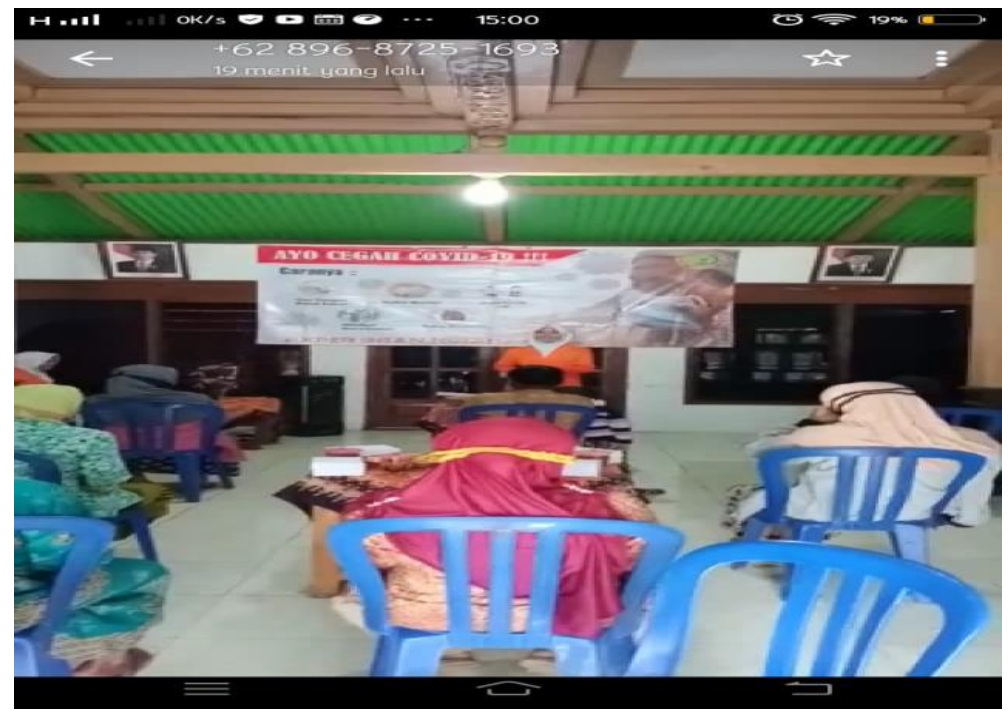

Gambar 3 . Penyuluhan kesehatan dan tanya jawab

Penyuluhan adalah suatu proses yang bertujuan untuk memberikan pengaruh pada pengetahuan, sikap dan prilaku seseorang ataupun kelompok. Peningkatan pengetahuan peserta dikarenakan sebagai hasil kegiatan penyuluhan ini dengan menggunakan teknik penyuluhan yang diikuti dengan adanya ceramah, tanya jawab dan demonstrasi. Penggunaan media merupakan suatu kompenen terpenting dalam suatu kegiatan penyuluhan (Johariyah \& Mariati, 2018). Hasil penelitian yang sama dengan temuan pada kegiatan ini dilaporkan bahwa ada perubahan pengetahuan, sikap dan ketrampilan ibu sebelum dan sesudah diberikan penyuluhan (Kapti et al., 2019).

Dari Hasil Pengabdian didapatkan peningkatan pengetahuan peserta yang mempunyai pengetahuan baik sebesar $80 \%$. Tim terus melakukan penguatan tentang keharusan melaksanakan protokol kesehatan dalam keseharian sebagai langkah pencegahan terinfeksi, memberikan kepercayaan diri kepada para peserta bahwa akan tetap sehat dan berjanji akan melaksanakannya. "Program Ingat Selalu 4M", Memakai Masker dengan benar, menjaga jarak, mencuci tangan memakai sabun, menghindari kerumunan harus terus didengungkan. Melalui kegiatan ini, tim memandang kegiatan ini harus terus dilakukan secara aktif dan berkesinambungan dengan sasaran dengan cakupan lebih besar dan individual seperti suami, anak, dan keluarga. Sehingga masyarakat memiliki pemahaman yang sama, sehingga pencegahan tertularnya COVID-19 dapat terjadi.

Dengan peningkatan pengetahuan diharapkan dapa meningkatkan kesadaran lansia dalam mematuhi protokol kesehatan, sehingga terhindar dari penyakit Covid 19. Untuk meningkatkan kesadaran masyarakat dalam pencegahan penularan virus Corona dalam keluarga dan masyarakat perlu dilakukan peningkatan pengetahuan melalui pendidikan kesehatan. Peningkatan pengetahuan masyarakat yang dimulai dari keluarga tentang mencegah penularan virus Corona penyebab Covid-19 sangat dibutuhkan untuk meningkatkan implementasi tindakan pencegahan penularan ini sehingga dapat menurunkan angka kejadian penyakit Covid-19. Hal ini sejalan dengan hasil penelitian yang menjelaskan bahwa ada hubungan antara pengetahuan responden dengan perilaku pencegahan COVID-19 di masyarakat. (Mujiburrahman dkk, 2020) 
b. Senam lansia

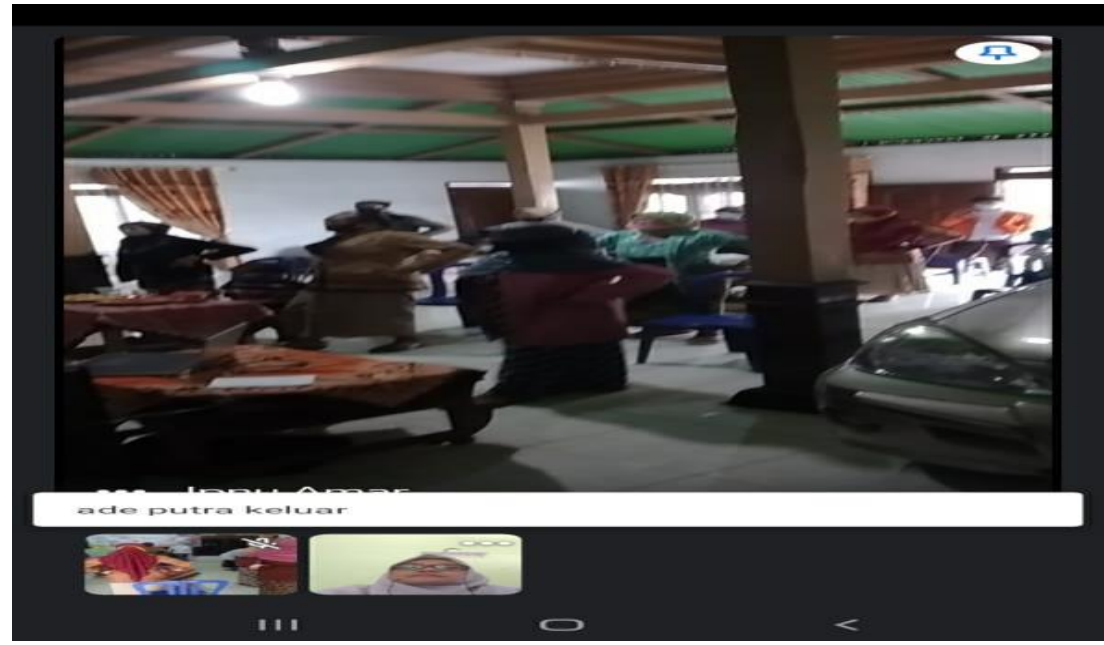

Gambar 4 . Senam Lansia

Senam adalah serangkaian gerak nada yang teratur dan terarah serta terencana yang dilakukan secara tersendiri atau berkelompok dengan maksud meningkatkan kemampuan fungsional raga untuk mencapai tujuan tersebut. Tahapan senam lansia adalah rangkaian proses dalam setiap latihan, meliputi pemanasan, kondisioning (inti), dan penenangan (pendinginan) (Sumintarsih, 2006). Semua senam dan aktifitas olahraga ringan tersebut sangat bermanfaat untuk menghambat proses degeneratif/penuaan. Senam ini sangat dianjurkan untuk mereka yang memasuki usia pralansia (45 thn) dan usia lansia (65 thn ke atas). Orang melakukan senam secara teratur akan mendapatkan kesegaran jasmani yang baik yang terdiri dari unsur kekuatan otot, kelentukan persendian, kelincahan gerak, keluwesan, cardiovascular fitness dan neuromuscular fitness. (Sumintarsih, 2006).

Hasil penelitian menyebutkan bahwa terdapat hubungan yang signifikan $(p=0,000)$ antara senam lansia terhadap kualitas hidup lansia yang menderita hipertensi (Saptarina dan Rabbaniyah, 2016). Hasil pengabdian didapatkan bahwa lansia yang hadir sangat antusias dan senang mengikuti senam yang diajarkan oleh penyuluh. Lansia diajarkan tentang gerakan-gerakan senam lansia dengan harapan agar lansia nantinya dapat menirukan dan melakukannya sendiri dirumah setiap hari. Senam lansia adalah olah raga ringan dan mudah dilakukan, tidak memberatkan yang diterapkan pada lansia. Aktifitas olahraga ini akan membantu tubuh agar tetap bugar dan tetap segar karena melatih tulang tetap kuat, mendorong jantung bekerja optimal dan membantu menghilangkan radikal bebas yang berkeliaran di dalam tubuh, sehingga dapat meningkatkan daya tahan tubuh seseorang.

\section{KESIMPULAN}

Kegiatan ini sangat bermanfaat bagi lansia dan keluarganya. Adanya peningkatan pengetahuan dan pemahaman lansia dalam upaya pencegahan COVID-19. Senam lansia ini diharapkan bisa dilaksanakan secara rutin di Posyandu Di Desa Gondosuli Tawangmangu Karanganyar Diharapkan lansia berpartisipasi aktif dalam kegiatan tersebut dengan tetap mematuhi protokol kesehatan $4 \mathrm{M}$. Kegiatan serupa perlu diadakan secara berkesinambungan agar dapat mencakup responden yang lebih banyak. 


\section{DAFTAR PUSTAKA}

Ausrianti, R., Andayani, R. P., Surya, D. O., \& Suryani, U. (2020). Edukasi Pencegahan Penularan Covid 19 serta Dukungan Kesehatan Jiwa dan Psikososial pada Pengemudi Ojek Online. Jurnal Peduli Masyarakat, 2(2), 59-64.https://siagacorona.semarangkota.go.id/.

Johariyah, A., \& Mariati, T. (2018). Efektivitas Penyuluhan Kesehatan Reproduksi Remaja Dengan Pemberian Modul Terhadap Perubahan Pengetahuan Remaja. Jurnal Manajemen Kesehatan Yayasan RS.Dr. Soetomo. https://doi.org/10.29241/jmk.v4i1.100

Kapti, R. E., Rustina, Y., \& Widyastuti. (2019). Efektifitas Audiovisual Sebagai Media Penyuluhan Kesehatan Terhadap Peningkatan Pengetahuan Dan Sikap Ibu Dalam Pemahaman Pemasangan IUD. Jurnal Ilmu Keperawatan. https://doi.org/10.1017/CB09781107415324.004

Kementerian Kesehatan RI. (2020). Pedoman Kesiapsiagaan Menghadapi Infeksi Novel Coronavirus (2019-nCoV). Jakarta: Kementerian Kesehatan RI.

Mujiburrahman, Riyadi M.E, Ningsih M.U. (2020). Hubungan Pengetahuan dengan Perilaku Pencegahan Covid-19 di Masyarakat. Jurnal Keperawatan Terpadu (Integrated Nursing Journal). Hal. 130-140. http: / /jkt.poltekkesmataram.ac.id/index.php/home/article/view/85

Nursalam \& Efendi, F. (2008). Pendidikan Dalam Keperawatan. Jakarta : Salemba Medika.

Pradana, A. A., Casman, C., \& Nur'aini, N.(2020). Pengaruh Kebijakan Social Distancing pada Wabah COVID-19 terhadap Kelompok Rentan di Indonesia. Jurnal Kebijakan Kesehatan Indonesia : JKKI, https://doi.org/10.22146/JKKI.55575

Saptarina, F., Rabbaniyah, F. (2016). Hubungan Senam Lansia terhadap Kualitas Hidup Lansia yang Menderita Hipertensi di Klinik HC UMMI Kedaton Bandar Lampung. JK Unila. https://juke.kedokteran.unila.ac.id/index.php/JK/article/view/1637

Setiawan GW, Wungouw HIS \& Pangemanan DHC. (2013). Pengaruh Senam Bugar Lanjut Usia (Lansia) Terhadap Kualitas Hidup Penderita Hipertensi. Jurnal e-Biomedik (eBm).

Sri Maria P.L, Hetti R, Yesi N, Maharani PP. (2021). Penyuluhan Pencegahan Penularan Covid-19 Dan Pembagian Masker Di Kecamatan Pedurungan Kota Semarang. JURNAL KREATIVITAS PENGABDIAN KEPADA MASYARAKAT (PKM), Volume 4 Nomor 3 Tahun 2021 hal. 487-493.

Sumintarsih. (2006). Kebugaran Jasmani untuk Lanjut Usia. Yogyakarta: UPN "Veteran"

World Health Organization. (2020). Anjuran mengenai penggunaan masker dalam konteks covid-19 ancaman krisis ekonomi global dari dampak penyebaran virus corona (covid-19) World Health Organization. (2020). Novel coronavirus (2019-nCoV). Situation report, 28. 